\author{
STATE OF ALASKA \\ Walter J. Hickel - Governor \\ DEPARTMENT OF NATURAL RESOURCES \\ Phil R. Holdsworth - Commissloner
}

DIVISION OF MINES AND MINERALS

James A. Wllllams - Director

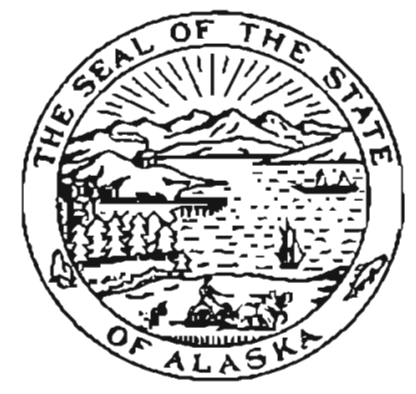

GEOLOGIC REPORT NO. 32

Geology of An Area On The Upper Talkeetna River, Talkeetna Mountains Quadrangle, Alaska

By

A.W. Rose

Juneau, Alaska

February 1967 


\section{CONTENTS}

Page

ABSTRACT

INTRODUCTION

REGIONAL GEOLOGY

ROCK UNITS

silleic Sehist and Gnelss

2

Schistose Greenstone and Greenstone

2

Phyllite

2

Argllllte, Slltstone, and Graywacke

2

LImestore

Andesite

Basalt

Quartz Dlorite Genlss

Gabbro

Tertiary(?) Andeslte, Basalt, and Related Rocks

2

2

3

3

3

STRUCTURAL GEOLOGY

ECONOMIC GEOLOGY

Locallty I

Locallty 2

Locality 3

Locality 4

Locallty 5

STREAM SEDIMENT GEOCHEMISTRY 


\title{
GEOLOGY OF AN AREA ON THE UPPER TALKEETNA RIVER, TALKEETNA MOUNTAINS QUADRANGLE, ALASKA
}

By Arthur W. Rose

\author{
ABSTRACT
}

In the central Talkeetna Mountains, a band of quartz dlorlte extends across the Talkeetna Rlver through an area mapped in old reports as maflc volcanics, and connects with another large granitic pluton to the northeast. Similarly, a northeast-trending belt of Mesozolc or older meta-sediments in the Iron Creek area a few miles southwest extends across the river and connects with a belt of sediments northeast of the rlver. This belt of sediments is the host for copper-lron deposits In the Iron Creek area. In the map area, the sediments are interlayered with greenstone.

Three minor copper occurrences were found during the mapping, and stream sediments derlved from a pyritic phyllite unit are moderately to strongly anomalous in copper content.

\section{INTRODUCTION}

From an aerial reconnaissance of the northern Talkeetna Mountalns in 1965, several zones within the present map area were recognized as strongly iron-stained (Rose, 1965). To follow up this indlcatlon, six days during September 1966 were spent mapping in the area and collecting stream sediment samples. The map area is about 15 miles northeast along the reglonal strike from the copper-iron deposits at Iron Creek (Capps, 1919). The writer was asslsted by L.J. Kerin, who collected most of the stream sediments. Access to the area was by llght plane to a gravel bar on the Talkeetna River. Don Sheldon of Talkeetna was very helpful in advising on access and transporting the party to and from the map area.

\section{REGIONAL GEOLOGY}

Previous geologic work in the northern Talkeetna Mountains has been incomplete and of reconnalssance nature at best (Capps, 1940). The reconnalssance mapping shows that the main part of the Talkeetna Mountains south of the Talkeetna Rlver is underlaln by a large granitic pluton, and another large, partly outlined pluton is present east and northeast of the map area. A northeast-trending belt of "pre-Cretaceous baslc lavas and tuffs and greenstone" plus minor Triassic limestone bounded on both sides by the granite pluton, trends toward the map area from the Iron Creek area to the southwest. A belt of sediments is also partly outlined northeast of the map area on 5 trlke with the belt. According to the older work, the belts of sediments and the granitic rocks are interrupted along the Yalkeetna River by baslc volcanlcs. The present work shows that the old mapping is incorrect in this respect. Unconformably overlying the older rocks is a sequence of Tertiary basalts and tuffs occupying the higher hills south of the Talkeetna River. 
ROCK UNITS

Slllcic Schist and Gneiss (55)

A zone adjacent to the granltic contact in the southeast part of the map area is composed predominantly of sillicic schist and biotlte-bearing schist and gnelss, along with some schlstose greenstone. The most distinctive llthology is a dark slliceous rock contalning scattered "eyes" of smoky gray quartz. The matrix of the rock conslsts of about $50 \%$ quartz along with plagioclase, blotite, and muscovlte. The texture and composition suggest that the rock, may be a metamorphosed dacite or daclte tuff which originally contained quartz phenocrysts. Other rock types in the unlt may be metamorphosed graywacke, and greenstone metasomatised by the granitic intrusive. Small areas of well-foliated quartz diorite are included in the unlt, as are numerous dikes of unfollated volcanlc rocks presumed to correlate with the Tertlary volcanlcs.

\section{Schistose Greenstone and Greenstone $(g)$}

The most common rock type in the area is greenstone and schistose greenstone, which occurs in several layers separated by other rock types. The greenstone varies from fine-grained to porphyritic, and occaslonally exhlbits banding or bedding. suggesting an orlgin of some greenstone as a mafic tuff or tuffaceous sediment. ThIn beds of metamorphosed chert or quartzite were found within the greenstone In one area. Vesicles and amygdules can be recognized in some zones. A speclmen of schlstose greenstone about a mile from the quartz diorlte gnelss contact is amphlbollte composed of blue-green hornblende and andesine, but most of the greenstone is less metamorphosed.

\section{Phyllite (ph)}

A belt of pyritic phyllite probably derlved from clastlc sediments is responsible for one of the prominent stained zones seen from the alr. Pyrlte comprises lo\% of some of the phyllite, and may have been introduced or redistributed by hypabyssal Intrusives possibly related to the Tertiary volcanics. The phyllite is up to 1,000 feet thick and can be traced about five miles. Greenstone lies on both sides of the phyllite.

\section{Argilllte, Slltstone, and Graywacke (ag)}

A belt of thin-bedded argillite, siltstone, and graywacke crosses the northern part of the map area, between two zones of greenstone. Much of the argllite is dark gray and has fair slaty cleavage.

A second exposure of arglllite and graywacke lles along the Talkeena River at the west corner of the area. The correlation of this sequence with those to the northeast is not clear.

$$
\text { Limes tone }
$$

Limestone is exposed within the argillite unit near the north end of the map area, and also as a thin bed within greenstone near 5 ample 28 in the northwest corner 
of the area. Aerial observatlons suggest that limestone forms the low hlll just north of the River, along strike, southwest from the latter occurrence in section 21 . The Il mestane at the north end of the area is slabby and cherty with phyllitic interbeds, and is considerably recrystallized, apparently by gabbro sills intruded along the beds. it is not clear whether there are several limestone beds that have been sheared out along strike, or one limestone that has been complexly folded and faulted.

\section{Andesite (a)}

Unfollated but highly fractured andesite with locally interlayered argllllte crops out north of the limestone and argillite units. This lithology was not noted in the northwest part of the map area.

\section{Basalt (b)}

Flne grained to aphanitic black basalt forms a small wedge in the north corner of the map area. A thin sectlon shows that thls basalt is composed mainly of fine actinolite with subordinate plagioclase and magnetite. Irregular gabbro intrusives occur within the basalt and along the contact wlth the andesite.

\section{Quartz Dlorlte Gnelss (qd)}

Well-follated quartz dlorite and granodiorite form the southern margin of the map area. Two thin sections indicate a composition of about $25 \%$ quartz, $10 \%$ hornblende and blotite, and 60\% andesine along with minor muscovite, orthoclase, and magnetlte. Float in the larger streams is all well-follated, indlcating that the follated rock makes up a large part of the pluton. Exposures on Yellowjacket Creek just south of the map area appear from the air to consist of layered sedlments or volcanlcs, so the granitic intrusive is only a few mlles wide where it crosses the Talkeetna River.

A second pluton of follated quartz diorite or granodiorite crops out in the extreme north end of the area. This body was visited in only one spot, but has been partly outlined from distant views. A thin section shows a composition of $25 \%$ quartz, 50\% andesine, $3 \%$ orthoclase, $7 \%$ hornblende, $3 \%$ blotlte, and minor magnetite and sphene.

\section{Gabbro $(g b)$}

Medium-grained gabbro occurs as sills in the argillite and limestone, and as Irregular intrusives in the basalt.

\section{Tertiary(?) Andesite, Basalt, and Related Rocks}

Numerous dikes and small irregular bodies of unfoliated hypabyssal andesite, basalt, and latlte(?) occur within the metamorphic units. They were partlculary noted along the Talkeetna River and at the southwest end of the phyllite unit. 
Within a zone about two miles wide bordering the southeastern quartz diorite gneiss, the volcanics and sediments have a good follation which is approximately parallel to the contact. Mylonites are locally present in the contact zone. The rocks near the cuntact show metamorphism to the amphibolite facles. The sediments and volcanics farther northeast are mostly unfollated and less metamorphosed, but minor folding and crumpling are common in the less competent sedimentary units.

In general the lithologlc units parallel the regional northeast trend, but individual units do not persist across the entire area. The andeslte and basalt at the extreme north of the map area were not recognized four miles southwest, and a unit of graywacke and argillite along the Talkeetna River was not identifled to the northeast. Most likely these units are faulted or sheared out by movements parallel to the quartz diorlte contact, but it is also posslble that close folding has caused offset of units.

The sedlments and volcanics of the map area almost certalnly correlate with the IImestone, slate, shale, quartzite, and greenstone of the Iron Creek area to the southwest, and with the slate, argillite, graywacke, and greenstone to the northeast. A Triassic age has been suggested for the sediments and a Jurasslc age (Talkeetna formation) for the greenstones (Capps, 1940, p. 70-74), but the ages of both these groups of rocks are based on rather tenuous correlations. The granltic intrusives of the region have been dated as Jurassic, and the sediments and volcanics are clearly older than the intruslves.

The continulty of the granitic rocks across the Talkeetna River suggests that the largest granitic body in the Talkeetna Mountains is elongated along the regional trend rather than belng two equant masses as shown on the geologlc map of Alaska (Dutro and Payne, 1957). The belt of sediments is also more continuous than previously realized.

\section{ECONOHIC GEOLOGY}

\section{Locality 1}

At this locality, highly-stained quartz dlorite gnelss with inclusions of biotite schist contains moderate to abundant pyrite and pyrrhotite, and traces of chalcopyrlte. Chlps from one of the most hlghly stained outcrops contained only $0.06 \%$ copper and traces of gold and silver.

\section{Locality 2}

This locality is a strongly stained patch about 200 feet in diameter on a steep hillside. Float below it includes gabbro with moderate amounts of disseminated pyrrhotite and traces of chalcopyrite disseminated and in veinlets.

\section{Locality 3}

A sample of highly altered phyllite from this vicinity contalned traces of gold and 5 ilver, but no copper, lead, or zinc. See the section on geochemistry for further discussion of the pyritic phyllite. 
Locality 4

A vein and replacement zone in a small gully at this locallty strikes N65E and dlps $70^{\circ}$ southeast. The zone cantains a few percent pyrrhotite and chalcopyrite replaclng greenstone across widths of six inches to two feet. A one inch quartz veln lles along one side of the zone. No alteration of the adjacent schistose greenstone (probably amphibollte) was noted.

\section{Locality 5}

A zone about a foot wide in altered argillite at this locality on the river is copper-stalned and contains minor chalcopyrite and pyrite. The zone 5 trikes $N 87 \mathrm{~W}$ and dips $54^{\circ} \mathrm{SW}$, almost parallel to bedding, and is located about 10 feet from the axial plane of a small isoclinal fold. Minor copper stain was also noted a few hundred feet upstream in pyritized and bleached greenstone.

\section{STREAM SEDIMENT GEOCHEMISTRY}

Thirty-nine stream sediment samples were collected from active stream channels in the area and have been analyzed for total copper, zinc, lead, molybdenum, and nickel after drying and sleving to -80 mesh. Based on the results for these stream sediments and others in the Alaska Range, contents hlgher than 150 ppm copper and 200 ppm zinc are considered anomalous. No definite anomalles are recognlized for lead, molybdenum, and nickel.

The moderate to strong copper anomalles in samples 23 and 26 are the most interesting feature of the data. Both streams draln the pyritic phyllite, and it is likely that the copper anomalles are related to the high suifide content of this unit. Samples 11 and 27 are weakly anomalous in copper and also drain the pyrltic phyllite. A sample of the phyllite collected at mineral locality 3 contained less than 500 ppm copper, but higher values almost certainly occur in some parts of the unit in order to furnish the sediment anomalies. Prospecting and additional sampling of this unit is definitely recommended.

Sample 14 is weakly anomalous in copper and has a relatively high nickel content. The sample was taken just below a zone of highly stained greenstone schist withln the silicic schist unit. The weak anomaly combined with the relatively small size of the stained zone does not encourage further work.

A weak zinc anomaly in sample 2 is outside the mapped area and cannot be evaluated.

\section{SUGGESTIONS FOR PROSPECTORS}

Additional sampling of stream sediments and rocks along the pyritic phyllte unlt should be undertaken in order to evaluate the origin of the copper anomalles in these dralnages. 
The belt of sedimentary rocks mapped in this project is almost certalnly the extension of the sediments of the Iron Creek area where copper-iron deposits replaclng limestones are known. Further exploration of this belt of sediments, especlally on the south slde of the Talkeetna River, seems worthwhlle to search for 5 imllar mineralization.

\section{REFERENCES}

Capps, S.R., 1919, Mineral resources of the western Talkeetna Mountalns: U.S. Geological Survey Bulletin 692-0, $0,187-205$.

Capps, S.R., 1940, Geology of the Alaska Railroad region: U.S. Geological Survey Bulletin 907.

Dutro, J.T., and Payne, T.G., 1957, Geologle map of Alaska: U.S. Geological Survey $1: 2,500,000$.

Rose, A.W., 1965, An derial reconnalssance In the northern Talkeetna Mountaln5: Alaska Division of Mines and Minerals, Annual Report for 1965, p. 57-59. 
Table 1. Geochemical Data on Stream Sediments

All analyses by Rocky Mountain Geochemical Laboratorles, Salt Lake City, Utah.

\begin{tabular}{|c|c|c|c|c|c|c|}
\hline \multirow{2}{*}{$\begin{array}{l}\text { Map } \\
\text { No. }\end{array}$} & \multirow{2}{*}{$\begin{array}{c}\text { Sample } \\
\text { No. }\end{array}$} & \multicolumn{5}{|c|}{ Concentration (ppm) } \\
\hline & & Copper & Zinc & Lead & Molybdenum & Nickel \\
\hline $\begin{array}{l}1 \\
2 \\
3 \\
4 \\
5\end{array}$ & $\begin{array}{l}6 N-323 \\
6 N-324 \\
6 N-325 \\
6 N-320 \\
6 N-319\end{array}$ & $\begin{array}{r}90 \\
100 \\
85 \\
95 \\
50\end{array}$ & $\begin{array}{r}85 \\
240 \\
65 \\
70 \\
80\end{array}$ & $\begin{array}{r}10 \\
10 \\
5 \\
5 \\
5\end{array}$ & $\begin{array}{l}2 \\
1 \\
2 \\
2 \\
2\end{array}$ & $\begin{array}{l}30 \\
10 \\
35 \\
45 \\
10\end{array}$ \\
\hline $\begin{array}{r}6 \\
7 \\
8 \\
9 \\
10\end{array}$ & $\begin{array}{l}6 N-318 \\
6 N-317 \\
6 N-322 \\
6 N-321 \\
6 E-748\end{array}$ & $\begin{array}{r}50 \\
65 \\
80 \\
90 \\
140\end{array}$ & $\begin{array}{r}35 \\
105 \\
95 \\
85 \\
100\end{array}$ & $\begin{array}{l}5 \\
5 \\
10 \\
10 \\
10\end{array}$ & $\begin{array}{l}2 \\
4 \\
2 \\
1 \\
1\end{array}$ & $\begin{array}{l}5 \\
15 \\
50 \\
35 \\
85\end{array}$ \\
\hline $\begin{array}{l}11 \\
12 \\
13 \\
14 \\
15\end{array}$ & $\begin{array}{l}6 E-749 \\
6 N-307 \\
6 E-756 \\
6 E-751 \\
6 N-312\end{array}$ & $\begin{array}{r}\frac{190}{105} \\
90 \\
190 \\
45\end{array}$ & $\begin{array}{r}115 \\
105 \\
80 \\
70 \\
65\end{array}$ & $\begin{array}{r}10 \\
5 \\
-5 \\
5 \\
5\end{array}$ & $\begin{array}{l}4 \\
2 \\
3 \\
1 \\
2\end{array}$ & $\begin{array}{r}85 \\
50 \\
20 \\
180 \\
-5\end{array}$ \\
\hline $\begin{array}{l}16 \\
17 \\
18 \\
19 \\
20\end{array}$ & $\begin{array}{l}6 N-313 \\
6 N-316 \\
6 N-315 \\
6 N-314 \\
6 N-308\end{array}$ & $\begin{array}{l}45 \\
35 \\
25 \\
30 \\
40\end{array}$ & $\begin{array}{l}75 \\
70 \\
55 \\
50 \\
35\end{array}$ & $\begin{array}{l}5 \\
5 \\
5 \\
5 \\
5\end{array}$ & $\begin{array}{l}3 \\
1 \\
1 \\
2 \\
2\end{array}$ & $\begin{array}{l}10 \\
40 \\
25 \\
30 \\
-5\end{array}$ \\
\hline $\begin{array}{l}21 \\
22 \\
23 \\
24 \\
25\end{array}$ & $\begin{array}{l}6 N-309 \\
6 N-310 \\
6 N-306 \\
6 N-311 \\
6 N-326\end{array}$ & $\begin{array}{l}135 \\
120 \\
460 \\
90 \\
115\end{array}$ & $\begin{array}{r}105 \\
130 \\
185 \\
100 \\
80\end{array}$ & $\begin{array}{r}5 \\
5 \\
10 \\
5 \\
10\end{array}$ & $\begin{array}{l}2 \\
3 \\
3 \\
4 \\
1\end{array}$ & $\begin{array}{l}50 \\
30 \\
45 \\
30 \\
35\end{array}$ \\
\hline $\begin{array}{l}26 \\
27 \\
26 \\
29 \\
30\end{array}$ & $\begin{array}{l}6 E-729 \\
6 N-303 \\
6 N-304 \\
6 N-305 \\
6 E-762\end{array}$ & $\begin{array}{r}\frac{420}{170} \\
140 \\
65 \\
60\end{array}$ & $\begin{array}{r}170 \\
130 \\
95 \\
95 \\
85\end{array}$ & $\begin{array}{l}10 \\
15 \\
10 \\
15 \\
20\end{array}$ & $\begin{array}{l}2 \\
3 \\
2 \\
2 \\
1\end{array}$ & $\begin{array}{l}25 \\
35 \\
80 \\
25 \\
20\end{array}$ \\
\hline $\begin{array}{l}31 \\
32 \\
33 \\
34 \\
35\end{array}$ & $\begin{array}{l}6 E-759 \\
6 E-758 \\
6 E-710 \\
6 N-300 \\
6 N-327\end{array}$ & $\begin{array}{l}60 \\
40 \\
40 \\
35 \\
35\end{array}$ & $\begin{array}{r}105 \\
80 \\
75 \\
80 \\
70\end{array}$ & $\begin{array}{l}5 \\
5 \\
5 \\
5 \\
10\end{array}$ & $\begin{array}{l}3 \\
2 \\
1 \\
1 \\
5\end{array}$ & $\begin{array}{l}25 \\
40 \\
25 \\
15 \\
10\end{array}$ \\
\hline $\begin{array}{l}36 \\
37 \\
38 \\
39\end{array}$ & $\begin{array}{l}6 N-302 \\
6 N-301 \\
6 N-329 \\
6 N-328\end{array}$ & $\begin{array}{r}65 \\
30 \\
105 \\
55\end{array}$ & $\begin{array}{l}75 \\
85 \\
90 \\
70\end{array}$ & $\begin{array}{r}5 \\
10 \\
10 \\
5\end{array}$ & $\begin{array}{l}2 \\
3 \\
3 \\
4\end{array}$ & $\begin{array}{l}10 \\
20\end{array}$ \\
\hline
\end{tabular}

